\title{
KINERJA APARATUR DALAM MENINGKATKAN KUALITAS PELAYANAN DI BADAN PENGHUBUNG PEMERINTAH PROVINSI KALIMANTAN TENGAH DI JAKARTA
}

\author{
Ichsan Fravidya Nugraha ${ }^{1}$, Khasan Effendy ${ }^{2}$, Dahyar Daraba ${ }^{3}$ \\ ${ }^{1,2,3}$ Institut Pemerintahan Dalam Negeri (IPDN) \\ Email: ichsanfravidyanugrha@gmail.com
}

\begin{abstract}
Abstrak
Penelitian ini bertujuan untuk mendeskripsikan bagaimana kinerja aparatur dalam meningkatkan kualitas pelayanan yang diselenggarakan oleh Badan Penghubung Pemerintah Provinsi Kalimantan Tengah di Jakarta. Penelitian ini menggunakan metode deskriptif dengan pendekatan kualitatif, di mana teknik pengumpulan data dilakukan melalui wawancara, observasi, dan telaahan dokumen. Penelitian ini difokuskan pada kinerja aparatur dalam meningkatkan kualitas pelayanan, yang menyoroti bagaimana kinerja aparatur, faktorfaktor yang berperan dalam kinerja aparatur, serta strategi yang digunakan dalam kinerja aparatur melalui analisis SWOT dan Litmust Test. Hasil penelitian menunjukkan bahwa kinerja aparatur dalam meningkatkan kualitas pelayanan di Badan Penghubung Pemerintah Provinsi Kalimantan Tengah di Jakarta belum terselenggara secara optimal. Beberapa kendala yang ditemui dalam kinerja aparatur dalam meningkatkan kualitas pelayanan disebabkan karena, kurangnya tingkat pendidikan, pengetahuan dan pengalaman yang dimiliki aparat. Selain itu terbatasnya jumlah aparat yang memiliki kemampuan teknis dan kesempatan dari setiap aparat untuk meningkatkan kemampuan melalui pendidikan dan latihan baik structural maupun fungsional, serta kesempatan untuk melanjutkan pendidikan ke jenjang yang lebih tinggi menyebabkan pelayanan belum terselenggara secara berkualitas.
\end{abstract}

Kata Kunci: Kinerja Aparatur, Kualitas Pelayanan.

\begin{abstract}
This study was aimed to investigate the performance of the workers of the Liaison Agency of the Central Kalimantan Provincial Government in delivering their services. This study employed the qualitative method with descriptive analysis. Data used in this studywere obtained through interview, observation, and document analysis. This study examined the performance of the workers in improving the quality of service and focused on the mechanism and strategy that the workers used in conducting their duties andidentification of the factors that affecting their performance. Then, all the datawere analyzed using the SWOT method and Litmust Test. The result of this study shows that the performance of the workers of the Liaison Agency of the Central Kalimantan Provincial Government is not optimal. Some of the difficulties that are found to be the reasons of the dissatisfied performance of the workers are the low level of education and knowledge and the lack of experience. Furthermore, there is only a few numbers of workers that have the technical capability, limited opportunity to improve their capability through education or training either in structural or functional form, and the limited chance to pursue higher education that caused the poor quality of service.
\end{abstract}

Keywords: Performance, Quality of Service. 


\section{A. PENDAHULUAN}

Sumber Daya manusia (SDM) dalam organisasi pemerintahan tercermin pada Pegawai Negeri Sipil (PNS)/Aparatur Sipil Negara (ASN) sebagai aktor pelaksana pemerintahan, yang merupakan perangkat sentral dari organisasi pemerintahan. Suatu organisasi yang ingin meningkatkan kinerjanya sangatlah tergantung pada upaya pimpinan tertinggi dalam merumuskan strategi dan langkah-langkah pengembangan SDM guna mewujudkan efektivitas dan efisiensi kerja dalam pencapaian tujuan organisasi. Untuk itu, Peningkatan SDM merupakan sesuatu hal yang mendesak untuk dilaksanakan, mengingat perubahan arah kebijakan pemerintah sebagaimana dikehendaki dalam Kabinet Indonesia Maju Jilid II.

Kewenangan yang diserahkan kepada pemerintah daerah melalui otonomi daerah dapat ditangani dengan baik manakala didukung oleh SDM yang profesional. Penyiapan sumber daya aparatur daerah perlu dilakukan karena kenyataannya menunjukkan bahwa kualitas sumber daya manusia di daerah otonom belum terlampau menjanjikan. Oleh karena itu, sebagai salah satu faktor internal yang strategis kualitas sumber daya manusia merupakan kunci utama yang dapat merubah berbagai kelemahan menjadi kekuatan serta mengubah tantangan menjadi peluang. Untuk dapat menangkap peluang yang terbuka di depan mata, maka upaya utama yang dilakukan oleh masyarakat dan pemerintah daerah adalah membangun sumber daya manusia yang berkualitas (Wasistiono dan Tahir, 2007:39).

Setiap organisasi memiliki landasan kebijakan yang berhubungan dengan penataan organisasi yang berhubungan dengan pembagian pekerjaan secara jelas dan transparan di antara SDM aparat yang dimiliki. Dengan adanya pembagian kerja yang jelas, setiap aparat akan memiliki motivasi dan disiplin dalam melaksanakan pekerjaan sesuai dengan porsi dan kemampuan yang dimiliki. Hal itu dimaksudkan untuk mencegah terjadinya kesenjangan dalam pelaksanaan pekerjaan kantor, yang dapat menimbulkan adanya rasa ketidakpuasan aparat, sehingga dalam melaksanakan tugas dan fungsi yang diemban, tingkat pencapaiannya menjadi tidak maksimal.

Hakekatnya kinerja aparatur di Badan Penghubung Pemerintah Provinsi Kalimantan Tengah di Jakarta, adalah upaya terencana untuk meningkatkan organisasi yang andal dan profesional, sebagaimana tertuang dalam tugas dan fungsi. Berdasarkan Peraturan Gubernur Kalimantan Tengah Nomor 60 Tahun 2016 Tentang Tugas Pokok dan Fungsi Badan Penghubung Pemerintah Provinsi Kalimantan Tengah di Jakarta. Mengingat Badan Penghubung Pemerintah Provinsi Kalimantan Tengah di Jakarta merupakan jembatan antara pemerintah pusat dan daerah, sekaligus sebagai etalase untuk mempromosikan potensi daerah di tingkat nasional dan internasional, maka peningkatan kinerja aparatur sangatlah penting artinya dalam proses penyelenggaraan pemerintahan, pembangunan dan pemberdayaan masyarakat di daerah.

Namun demikian, keseluruhan program tersebut belum terlaksana dengan baik karena kurangnya dukungan kualitas SDM yang dimiliki oleh Badan sehingga kinerja yang dicapai belum optimal. Hasl itu disebabkan karena tingkat pendidikan yang dimiliki sebagian besar aparat berpendidikan SLTA, sehingga belum menjamin keberhasilan dalam melaksanakan tugas dan fungsi, karena kurangnya tingkat pendidikan yang dimilikinya. Kondisi yang demikian, tentunya cukup berpengaruh bagi aparatur dalam penyelenggaraan tugas dan fungsi yang diemban, terutama dalam fasilitasi dan pelayanan yang diberikan. 
Di sisi lain pelaksanaan program dan kegiatan yang dikaitkan dengan dokumendokumen perencanaan daerah belum terselenggara dengan baik, karena kurangnya komunikasi dan koordinasi yang terbangun di antara sub bagian yang ada di Badan, sehingga berdampak pada belum optimalnya pelaksanaan tugas dan fungsi, terutama dalam mempromosikan potensi daerah kepada pihak luar. Demikian pula dalam pengelolaan anggaran belum terlaksana dengan baik, karena masih ada kegiatan-kegiatan pembangunan yang penyerapan dananya belum mencapai target.

Masih lambatnya pelaksanaan tugas-tugas yang dilaksanakan aparat di lingkungan Badan Penghubung Pemerintah Provinsi Kalimantan Tengah di Jakarta disebabkan karena berbagai permasalahan sesuai laporan akuntabilitas kinerja dalam perjanjian kinerja bahwa; kebijakan Tim Anggaran Pemerintah Daerah (TAPD) dalam penentuan anggaran prioritas khususnya dalam kegiatan rutin kantor sehingga kegiatan tidak menunggu persediaan anggaran hasil Dokumen Pelaksanaan Anggran (DPA) perubahan sedangkan kebutuhan rutin sifatnya sangat mendesak.

Sesuai dengan hasil pengamatan awal yang dilakukan penulis, terlihat bahwa kinerja aparat di Badan Penghubung Pemerintah Provinsi Kalimantan Tengah di Jakarta belum memperlihatkan unjuk kerja sebagaimana yang diharapkan. Kondisi yang demikian menyebabkan pekerjaan yang seharusnya diselesaikan tepat waktu menjadi terbengkalai atau membutuhkan waktu lama dalam penyelesainnya. Belum tercapainya kinerja sebagaimana yang diharapkan organisasi Badan. Adanya tugas atau pekerjaan yang dilakukan hanya pada saat ada perintah atau instruksi langsung dari atasan, hal ini dilandasi pada sebagian aparat belum menyadari akan tugas dan tanggung jawabnya. Kurangnya etos kerja dalam mematuhi aturan jam kerja tersebut, disebabkan karena kurangnya motivasi yang diberikan oleh atasan yang ditunjang oleh kondisi lingkungan kerja yang kurang mendukung, sehingga kinerja aparat belum dicapai secara optimal di lingkungan Badan Penghubung Pemerintah Provinsi Kalimantan Tengah di Jakarta.

\section{B. TINJAUAN PUSTAKA}

Dalam proses penyelenggaraan fungsi pemerintahan, tidak dapat dipungkiri bahwa aparatur pemerintah yang tersebar pada setiap struktur organisasi semakin dibutuhkan kemampuan profesional dan kinerjanya dalam menghasilkan suatu pekerjaan yang berkualitas sesuai dengan tugas dan fungsi yang diemban. Tekad pemerintah dalam rangka membenahi SDM (aparatur) dimaksudkan agar setiap aparat dapat meningkatkan kualitas maupun kuantitas pelayanan secara efektif, efisien, dan berorientasi pada kinerja. Mencermati pemaknaan itu, maka seluruh Pegawai Negeri Sipil (PNS) /Aparatur Sipil Negara (ASN) terutama yang berada digaris depan yang berhubungan langsung dengan masyarakat dalam menyelenggarakan pelayanan seyogyanya dapat mereformasi diri agar mampu untuk memenuhi bahkan mencapai apa yang telah menjadi tuntutan dari program pemerintah.

Memaknai pandangan di atas, tidaklah berlebihan jika dikatakan bahwa, sumber daya manusia merupakan satu-satunya sumber daya yang memiliki akan perasaan, keinginan, keterampilan, pengetahuan, dorongan, daya, dan karya (rasio, rasa, dan karsa). Semua potensi SDM tersebut berpengaruh terhadap upaya organisasi dalam mencapai tujuan (Sutrisno, 2014:3). Lebih lanjut dalam pandangan Esman (1989:53) bahwa "barangkali sumber daya 
yang paling penting untuk sebuah organisasi adalah stafnya (aparat) yang memiliki pengetahuan dan keahlian serta mempunyai komitmen terhadap organisasi”.

Dalam menentukan apakah seorang aparatur mempunyai kinerja baik, sedang atau buruk maka perlu dilakukan penilaian terhadap kinerja Oleh karena itu, perlu ditelusuri dengan melakukan identifikasi masalah, mencari faktor penyebabnya, dan minta pendapat pegawai tentang solusi yang efektif untuk dapat mengatasinya. Menurut Wibowo (2017:233) bahwa "masalah yang dapat berkaitan dengan kinerja dapat berupa; kemampuan, pelatihan, motivasi, gangguan, dan pengasingan". Guna mengatasi masalah kinerja perlu dilakukan identifikasi masalah, mencari faktor penyebabnya, dan minta pendapat pegawai tentang solusi yang efektif untuk mengatasi, sehingga terjalin komunikasi timbal balik antara atasan dan bawahannya (aparatnya).

Penilaian kinerja memberikan basis bagi keputusan-keputusan yang mempengaruhi gaji, promosi, pemberhentian, komitmen organisasi transfer dan kondisi-kondisi kepegawaian lainnya. Menurut Robbins (2006:218) "tingkat kinerja pegawai akan sangat tergantung pada faktor kemampuan pegawai itu sendiri seperti tingkat pendidikan, pengetahuan, pengalaman dimana dengan tingkat kemampuan yang semakin tinggi akan mempunyai kinerja semakin tinggi pula". Lebih lanjut untuk mengetahui kinerja pegawai pemerintah dalam menyelesaikan tugas dan fungsinya, Bernardin \& Russel (2006:239) mengemukakan bahwa "A way of measuring the contribution of individuals to their organization". Artinya bahwa penilaian kinerja adalah cara mengukur konstribusi individu (aparatur) kepada organisasi tempat mereka bekerja. Lebih lanjut dikatakan bahwa terdapat beberapa indikator kinerja aparatur antara lain quality, quantity, timeliness, cost effectiveness, need for supervision, dan interpersonal impact.

Berpedoman dari beberapa beberapa pendapat di atas, dapat dimaknai bahwa kinerja merupakan hasil kerja secara kualitas dan kuantitas yang dicapai oleh seseorang pegawai dalam melaksanakan tugasnya sesuai tanggung jawab yang diberikan kepadanya dalam kurun waktu tertentu. Kinerja pegawai ditentukan oleh tujuan yang hendak dicapai dan untuk melakukannya diperlukan adanya motivasi dan inovasi yang tinggi. Tanpa dorongan motivasi yang tinggi untuk mencapai tujuan, maka kinerja tidak mungkin akan dapat dicapai sesuai dengan tujuan organisasi.

\section{METODE}

Suatu penelitian ilmiah yang dilakukan apapun bentuk dan macamnya selalu membutuhkan metode dan atau desain penelitian guna menentukan dan mengkaji atau menganalisis keabsahan akan suatu fenomena yang diteliti. Desain penelitian adalah semua proses yang diperlukan dalam perencanaan dan pelaksanaan penelitian” (Nazir, 2011:84). Sementara menurut Arikunto (2016:136), "metode penelitian adalah cara yang digunakan oleh peneliti dalam mengumpulkan data penelitiannya".

Metode yang digunakan dalam penelitian ini adalah metode kualitatif, guna mengungkapkan fenomena secara mendetail. Kelebihan metode kualitatif adalah kemampuannya mengungkap fenomena secara mendetail sehingga memberi pencerahan (Alwasilah (2011:97). Pendapat yang hampir sama dikemukakan Strauss \& Corbin (2003:5) bahwa "metode kualitatif dapat memberikan rincian yang kompleks tentang fenomena yang sulit diungkapkan oleh metode kuantitatif". 
Penelitian ini menggunakan desain penelitian kualitatif dengan pola pendekatan deskriptif yang bercirikan kegiatan penggumpulan, menggambarkan dan menafsirkan data tentang situasi yang dialami, hubungan kegiatan, pandangan, sikap yang ditunjukkan; atau tentang kecendrungan yang tampak dalam proses yang sedang berlangsung, bertentangan yang meruncing serta kerjasama yang dijalankan. Dengan demikian, penelitian ini menggambarkan bagaimana kinerja aparatur dalam meningkatkan kualitas pelayanan, dan faktor-faktor apa yang mempengaruhinya guna meningkatkan kinerja aparatur di Badan Penghubung Pemerintah Provinsi Kalimantan Tengah di Jakarta.

Sehubungan dengan sumber data, Arikunto (2016:114) mengatakan: "Sumber data dalam penelitian adalah subjek dari mana data dapat diperoleh." Sedangkan Ndraha (1985:61) mengatakan: "Sumber data bermacam-macam: alam, masyarakat, instansi, arsip, perpustakaan dan sebagainya". Untuk itu dalam penelitian ini sumber data yang berasal dari responden atau masyarakat, berbagai dokumen atau arsip, instansi dan perpustakaan. Lebih lanjut Hamdi \& Ismaryati (2014:6.28) mengemukakan bahwa data yang dibutuhkan dalam penelitian kualitatif dapat berupa data primer dan data sekunder". Sementara untuk memperoleh informasi penellitian, maka digunakan informnan. Moleong (2014:90), mengemukakan bahwa "informan adalah orang yang dimanfaatkan untuk memberikan informasi tentang situasi dan kondisi latar penelitian". Tata cara penentuan informan dalam penelitian ini menggunakan teknik purposive dan snowball.

Langkah berikutnya adalah dalam suatu penelitian adalah proses pengumpulan data. Pengumpulan data merupakan langkah yang amat penting dalam metode ilmiah karena pada umumnya dapat dikumpulkan dan digunakan kecuali untuk penelitian eksploratif, untuk menguji hipotesa yang telah dirumuskan. Pengumpulan data adalah prosedur yang sistematik dan standar untuk memperoleh data yang diperlukan (Nazir, 2011:174). Teknik pengumpulan data yang akan digunakan dalam penelitian ini adalah teknik wawancara, obsevasi, dan dokumentasi.

Keseluruhan data yang telah berhasil diperoleh selanjutnya dianalisis secara terusmenerus berdasarkan input, proses dan output yang terjadi di lingkungan Badan Penghubung Pemerintah Provinsi Kalimantan Tengah di Jakarta, mulai dari awal penelitian hingga pada akhir penelitian. Data-data yang terkumpul dirangkum, diseleksi sesuai dengan konsepkonsep dalam penelitian selanjutnya diuji kebsahannya dan disajikan dalam pemaparan deskriptif. Sementara untuk menganalisa strategi yang tepat dalam kinerja aparatur guna meningkatkan kualitas pelayanan di Badan Penghubungan Pemerintah Provinsi Kalimantan Tengah di Jakarta, peneliti menggunakan analisis SWOT (Strengths, Weaknesses, Opportunities, Treaths) dan Litmus Test.

\section{HASIL DAN PEMBAHASAN}

\section{Kinerja Aparatur Dalam Meningkatkan Kualitas Pelayanan}

Penilaian kinerja dimaksudkan untuk menilai berhasil tidaknya tugas dan fungsi yang diemban, sekaligus dipergunakan sebagai dasar penyusunan sistem imbalan atau sebagai dasar penyusunan strategi organisasi. Dalam pandangan Robbins (2006:218) dijelaskan bahwa "tingkat kinerja pegawai akan sangat tergantung pada faktor kemampuan pegawai itu sendiri seperti tingkat pendidikan, pengetahuan, pengalaman dimana dengan tingkat kemampuan yang semakin tinggi akan mempunyai kinerja semakin tinggi pula". Ketiga 
aspek tersebut akan menjelaskan bagaimana kinerja aparatur dalam meningkatkan kualitas pelayanan di Badan Penghubung Pemerintah Provinsi Kalimantan Tengah di Jakarta.

a. Aspek Tingkat Pendidikan

Aparatur pemerintah memiliki peran dalam mengelola kekuasaan pemerintahan melalui tugas dan fungsi yang diselenggarakan seyogyanya berperilaku dan bertindak secara benar sesuai dengan nilai-nilai dan norma yang berlaku di dalam tataran kehidupan masyarakat. Melalui kemampuan yang dimiliki, seseorang aparat dapat menjaga sikap dan kepribadiannya berdasarkan tugas dan tanggung jawab secara berdayaguna dan berhasil guna. Dengan kemampuan dimiliki tersebut, setiap aparat dapat memahami memahami visi misi organisasi, sebagai landasan berpijak dalam menjalankan tugas dan fungsinya dalam meningkatkan kualitas pelayanan.

Namun demikian, realitas yang ditemui di lapangan menunjukan bahwa aparat yang bertugas di Badan Penghubung yang berjumlah 16 orang di dominasi oleh aparat yang memiliki pendidikan setingkat dengan SLTA. Dengan kondisi yang demikian, menyebabkan sebagaian aparat belum memiliki wawasan terhadap konsep yang berkaitan dengan pelayanan, dan memahami sejumlah peraturan yang berkaitan dengan tugas dan fungsi yang dijalaninya. Organisasi Badan berupaya untuk meningkatkan kemampuan yang dimiliki setiap aparat, pendidikan dan pelatihan (Diklat) struktural dan fungsional serta bimbingan teknis (Bintek), namun hal itu belum terlaksana dengan baik. Hal itu karena, Diklat atau Bintek yang diadakan, baik oleh Pemerintah Pusat atau Daerah sering bersamaan dengan kegiatan fungsi pelayanan pimpinan atau promosi yang dilakukan Bandan Penghubung, sehingga kegiatan Diklat tersebut tidak diikuti.

Belum optimalnya proses penyelenggaraan pelayanan sebagaimana yang disampaikan, merupakan fenomena yang perlu menjadi perhatian dari para pimpinan guna memperhatikan apa saja yang diinginkan oleh para bawahan, dan bukan hanya melalui sistem perintah. Sebenarnya yang diinginkan oleh para bawahan adalah bagaimana mereka dihargai oleh pimpinan, setelah tanggung jawab yang diberikan dapat diselesaikan dengan baik.

Harapan sebagaimana dijelaskaan di atas, perlu dicermati melalui adanya langkahlangkah strategis dalam mengembangkan setiap potensi dan kemampuan yang dimiliki setiap aparat dalam penyelenggaraan tugas dan fungsinya. Upaya meningkatkan mutu pelayanan, pada awalnya harus dimulai dengan meningkatkan dan mengembangkan kemampuan setiap individu dalam organisasi. Pengembangan sumber daya setiap aparat dapat diarahkan pada jalur yang lebih professional, guna meningkatkan kemampuan secara pribadi maupun sesuai kebutuhan organisasi pemerintahan.

Peningkatan pendidikan dan pelatihan teknis di atas, memiliki tujuan agar setiap aparat mampu mengembangkan kemampuan yang dimiliki, membangun lingkungan kerja yang harmonis dengan inovasi dan kreativitas yang dimiliki guna meningkatkan kinerjanya. Salah satu penentu utama inovasi adalah tantangan dalam lingkungan organisasi, karena inovatif memberi tekanan kuat pada kualitas. Dengan dukungan manajerial untuk inovasi sangat menentukan, jika apabila sumber daya aparat yang dimiliki dapat dikembangkan dan melaksanakan ide dan cara baru yang lebih baik dalam mengerjakan berbagai tugas dan fungsi yang dijalaninya. 
b. Aspek Pengetahuan

Dalam organisasi pemerintah daerah, sumber daya aparatur sangatlah penting artinya, karena melalui pengetahuan yang dimiliki maka diharapkan mampu melakukan terobosan terutama mempermudah mekanisme penyelenggaraan tugas dan fungsi sehingga kinerja pelayanan dapat ditingkatkan. Oleh sebab itu, seyogyanya organisasi badan menciptakan suasana yang harmonis agar setiap aparat dapat berkerja lebih maksimal, sesuai bidang ilmu yang dimiliki. Dengan kecintaan setiap aparat terhadap iklim dan suasana kerja yang harmonis, akan memberi dorongan untuk bekerja lebih giat dan kreatif, dalam menyelenggarakan tugas dan fungsi terutama dalam menyelenggarakan pelayanan yang berkualitas.

Sebenarnya pada sub bagian, terdapat beberapa aparat yang memiliki potensi, namun kemampuan yang dimiliki itu belum dimanfaatkan secara maksimal. Memang diakui oleh sebagian aparat yang ditugaskan pada Badan Penghubung merasa bahwa, mereka merupakan pegawai buangan yang kurang diperhatikan oleh Pemda, sehingga hal itu tentunya dapat memberi dampak pada tugas yang dijalaninya. Dengan demikian, persoalan tersebut haruslah disikapi oleh pimpinan organisasi untuk mengambil langkah-langkah, dalam memberdayakan aparat secara maksimal, sehinga dapat memanfaatkan potensi mereka secara maksimal demi suksesnya organisasi.

Menyikapi hal dimaksud, keseluruhan aparatur termasuk pimpinan organisasi, senantiasa dituntut mengembangkan kemampuan dan pengetahuan, sebagai modal dalam melaksanakan tugas dan fungsinya sesuai yang tertera dalam struktur organisasi. Dengan memiliki tingkat pengetahuan yang tinggi dari setiap aparat, diharapkan dapat mewujudukan pelayanan yang berkualitas dan efektif, terutama dapat berperan sebagai penghubung antara Pemerintah Pusat dan Daerah, sekaligus dapat mempromosikan potensi sumber daya yang dimiliki daerah ke pihak luar secara optimal.

Namun demikian, Badan Penghubung sebagai organisasi publik yang menyediakan pelayanan, belum berupaya memaksimalkan pengetahuan yang dimiliki oleh setiap aparatur. Dengan keterbatasn aparat yang dimiliki, yang umumnya memiliki pengetahuan yang minim, tentunya tugas dan fungsi itu belum dapat diselenggarakan secara optimal. Dengan kurangnya kualitas sumber daya aparat yang dimiliki, serta kurangnya pemahaman terhadap tugas dan fungsi yang diberikan menyebabkan program-program yang telah disusun oleh masingmasing sub bagian belum mencapai hasil sebagaimana yang telah ditetapkan.

Kurangnya tingkat pengetahuan yang dimiliki oleh aparat pelaksana, menyebabkan program-program strategis belum mencapai hasil terlihat dari proses penyerapan anggaran yang belum optimal. Oleh sebab itu, peningkatan pengetahuan yang dimiliki setiap aparat, dapat dilakukan melalui program tugas belajar, baik untuk program strata I (Sarjana) ataupun Strata II (Pasca Sarjana) kepada aparat yang memiliki potensi untuk dikembangkan. Keikutsertaan aparat dalam program tugas belajar tersebut, disatu sisi setiap aparat merasa diperhatikan oleh pimpinan organisasi yang lebih tinggi, di sisi yang lain dengan pengetahuan yang dimiliki diharapkan tugas dan tanggung jawab yang diberikan kepadanya setiap aparat dapat terlaksana sesuai yang diharapkan.

c. Aspek Pengalaman

Tuntutan masyarakat terhadap perbaikan dan penyempurnaan tata layanan pemerintahan dewasa ini, telah menyebabkan semakin intensifnya intervensi pemerintah 
dalam segala aspek kehidupan masyarakat. Untuk itu dibutuhkan kecakapan dari setiap aparat dalam melaksanakan tugas, yang berarti dibutuhkan kemampuan dalam menguasai bidang tugas yang dilajaninya. Artinya bahwa setiap program kerja yang ditetapkan organisasi, akan diimplementasikan sesuai dengan metode dan standar prosedur kerja, yang didukung oleh iklim suasana kerja yang kondusif yang lebih berdayaguna dan berhasilguna.

Namun demikian, dengan kurangnya pengalaman yang dimiliki dari setiap aparat penyelenggara layanan, sehingga program-program yang telah disusun organisasi, belum mencapai hasil sebagaimana yang telah ditetapkan. Sementara kesempatan untuk meningkatkan kemampuan dari aparat tersebut sangat terbatas, menyebabkan sebagaian aparat kurang tanggap terhadap tugas dan fungsinya yang dijalani. Kenyataannya seringkali pekerjaan kantor menjadi kurang diselesaikan tepat pada waktunya, sehingga perlu ada pembinaan dan bimbingan agar setiap aparat taat dan patuh dalam melaksanakan tugas yang dijalani.

Kurangnya rasa tanggung jawab yang diperlihatkan, karena distribusi pekerjaan yang dilakukan pimpinan kepada para bawahannya yang kurang sesuai dengan bidang tugasnya. Kondisi demikian sebenarnya dapat dipahami, mengingat sebagian aparat belum berpengalaman, di samping kurangnya perhatian dari pimpinan dalam memperhatikan para bawahannya secara keseluruhan, terutama dalam mendistribusikan pekerjaan kepada setiap aparat sesuai dengan bidang tugasnya masing-masing. Hal itu berdampak pada penyelesaian pekerjaan tidak tepat waktu, karena aparat sering membuat kekeliruan dalam proses penyelesaian layanan, sehingga pada pihak yang dilayani belum merasa puas terhadap layanan yang diberikan.

Padahal, berhasil tidaknya organisasi publik tergantung dari kemampuan setiap aparat dalam mengantisipasi berbagai masalah yang muncul dari berbagai p[ihak yang dilayani, sekaligus mencari solusi yang terbaik. Oleh sebab itu, setiap aparat seharusnya taat dan patuh terhadap setiap aturan yang belaku dan tanggap terhadap tugas dan fungsi yang diemban. Namun demikian, belum taat dan kepatuhan yang dimiliki penyelenggara layanan, menyebabkan sebagian aparat kurang dapat mengantisipasi berbagai keluhan dari berbagai pihak yang dilayani.

Dalam rangka merealisasikan hal dimaksud, dibangun jalinan kerjasama dan komunikasi yang bertujuan agar setiap aparat dapat membangun lingkungan kerja yang harmonis dalam melaksanakan tugas dan tanggung jawabnya. Namun demikian, kenyataannya dalam proses penyelenggaraan tugas dan fungsinya, masing-masing aparat masih memperlihatkan sikap yang lebih mendahulukan kepentingan pribadi. Kurangnya kerjasama sebagai yang dibangun di antara tiap aparat sebagai suatu bentuk berbagi pengalaman, menyebabkan program kerja yang telah disusn dan dilaksanakan belum dapat diselesaikan tepat waktu, dan mencapai target sesuai yang ditetapkan.

\section{Faktor-Faktor Yang Berperan Dalam Kinerja Aparatur Guna Meningkatkan Kualitas Pelayanan}

Kinerja aparatur demikian penting artinya dalam rangka membangun citra organisasi pemerintahan dimata publik melalui tugas dan fungsi yang dilaksanakan. Pemahaman terhadap kinerja aparatur menunjuk pada tingkat pencapaian hasil kerja yang dicapai oleh seseorang aparat atau sekelompok aparat dalam suatu organisasi, sesuai dengan wewenang 
dan tanggung jawabnya. Hal itu sejalan dengan pendapat Zainun (2001:50) bahwa "di antara berbagai sumber daya yang dimiliki oleh sebuah organisasi, sumber daya manusia merupakan sumber daya yang paling strategis dan menentukan kedudukannya bagi keberhasilan organisasi dalam mencapai tujuan dan sasarannya". Artinya bahwa walaupun terdapat kesiapan berbagai falisilitas yang lengkap dalam organisasi, namun pada akhirnya yang akan mengelola dan memanfaatkan berbagai sumber daya itu adalah sumber daya manusia.

Dengan demikian, organisasi akan mencapai hasil sesuai dengan tujuan yang telah ditetapkan, jika didukung oleh sumber daya aparatur yang memiliki kemampuan dalam melaksanakan tugas dan tanggung jawab yang diemban Untuk mengukur kontribusi dari setiap aparat dalam menyelenggarakan tugas dan fungsinya sesuai keinginan organisasi. Sebagaimana dalam pandangan Bernardin dan Russel (2006:239) dikatakan bahwa terdapat beberapa aspek dalam lingkup kinerja aparatur antara lain; quality, quantity, timeliness, cost effectiveness, need for supervision, dan interpersonal impact. Pemahaman terhadap keenam aspek tersebut yang akan membahas tentang faktor-faktor yang berperan dalam kinerja aparatur guna meningkatkan kualitas pelayanan di Badan Penghubung Pemerintah Provinsi Kalimantan Tengah di Jakarta.

a. Faktor Quality

Penyiapan sumber daya aparatur yang memiliki kemampuan diperlukan terutama dalam menganalisis berbagai problem dalam penyelenggaraan pemerintahan, pembangunan dan pelayanan publik. Kunci terbesar keberhasilan terletak pada kemampuan meningkatkan profesionalisme, dalam arti melaksanakan aktivitas usaha secara efisien, efektif dan produktif, sehingga dapat bertahan dan berkembang (survive), terutama dalam menyelenggrakan pelayanan yang berkualitas kepada masyarakat (Sanjaya, 2006:125).

Bernadin dan Russel (2006:239) bahwa "Quality: the degree to witch the process or result of carrying out an activity approaches perfection, in terms of either conforming to some ideal way of performing the activity for fulfilling the activity;s intended purpose". Artinya quality adalah tingkat sejauh mana proses atau hasil pelaksanaan kegiatan mendekati kesempurnaan atau dengan kata lain mendekati tujuan yang diharapkan. Namun demikian, realitas menunjukkan bahwa kinerja aparatur masih belum dapat dicapai secara optimal karena kurangnya kemampuan yang dimiliki aparat.

Sebenarnya aparat terus berupaya untuk meningkatkan kinerja, melalui berbagai bimbingan dan arahan yang biasanya dilakukan melalui rapat staf oleh pimpinan. Kegiatan tersebut dilaksanakan setiap sebulan sekali untuk menerima berbagai masukan dan pendapat dari aparat terhadap tugas dan fungsi yang dilaksakan. Namun, walaupun kegiatan tersebut terus diupayakan dalam rangka memperbaiki kinerja, tetapi hal tersebut belum memberikan dampak ke arah yang lebih baik. Salah satu faktor penyebab karena kurangnya perhatian organisasi secara menyeluruh kepada setiap aparat yang ada sesuai dengan mekanisme dan prosedur yang berlaku.

Fenomena di atas, seyogyanya disikapi oleh pimpinan organisasi untuk mengawasi setiap aparat dalam menjalankan tugas dan fungsinya. Sebab peran serta aparatur pemerintah dalam memberikan pelayanan, terlihat dalam berperilaku dan bertindak secara benar dan sesuai dengan nilai dan norma berlaku, sehingga pihak yang dilayani merasa puas terhadap layanan pemerintahan yang diberikan. Sehubungan dengan maksud tersebut, maka aparatur yang menjadi tulang punggung dalam setiap aktivitas pemerintahan perlu diberdayakan, 
dalam arti ditempatkan sesuai dengan dan kemampuan yang dimiliki agar program kerja yang dilaksanakan dapat mencapai target.

Realitas yang ditemui di lapangan memperlihatkan bahwa program kerja yang dilaksanakan aparat, sering dilakukan tidak sesuai dengan metode atau prosedur yang telah berlaku. Pelaksanaan pekerjaan terkadang tidak sesuai dengan aturan yang telah ditetapkan dalam organisasi. Hal ini memberi kesan bahwa lebih baik melaksanakan pekerjaan walaupun itu salah, dari pada tidak sama sekali, sehingga terlihat bahwa sebagian aparat memiliki kecenderungan tidak kreatif dalam melaksanakan program-program yang telah disusun organisasi, sehingga layanan yang diberikan belum mencapai hasil secara maksimal.

Kurangnya disiplin yang diperlihatkan dengan memberikan pelayanan yang kurang optimal karena. sebagian aparat belum sepenuhnya mentaati aturan dalam organisasi, sehingga berdampak pada pencapaian hasil kerja yang belum maksimal. Oleh sebab itu, salah satu aspek yang perlu diperhatikan untuk menciptakan kondisi aktivitas kerja yang lebih kontinyu dan terarah bagi setiap aparat, adalah perhatian organisasi terhadap apa yang dibutuhkan. Melalui motivasi yang diberikan segenap unsur pimpinan, diharapkan mereka taat dan patuh terhadap aturan yang berlaku sehingga dapat menyelesaikan berbagai program tepat pada waktunya sebagaimana diharapkan organisasi.

\section{b. Faktor Quantity}

Kedudukan dan arti penting faktor sumber daya aparat dalam organisasi hanya akan menjadi nyata dan berguna secara riil, manakala dengan kemampuan yang dimiliki dapat memberikan manfaat yang optimal bagi organisasi. Hal itu sebagaimana dikemukakan Bernadin dan Russel (2006:239) bahwa "Quantity: The amount produced, expressed in such terms as dollar value, number of units or number of completed activity cycles". Artinya quantity merupakan jumlah yang dihasilkan dalam aktivitas kerja, misalnya jumlah uang, jumlah unit, dan jumlah siklus kegiatan yang telah diselesaikan.

Pada dasarnya produk layanan pemerintahan merupakan satu bundel jasa yang disediakan untuk memuasi kebutuhan berbagai pihak. Guna memperoleh produk layanan tersebut, sumber daya aparat yang dimiliki organisasi perlu dikerahkan untuk memberikan pelayanan yang prima. Artinya produk yang diterimanya memiliki nilai atau kualitas yang baik, mudah diperoleh pada saat dibutuhkan, bebas dari kekeliruan atau cacat dan diperoleh dalam waktu yang relatif pendek, murah, adil dan mudah dijangkau. Nasution (2001:16) mengatakan kualitas itu, sebagai "suatu kondisi dinamis yang berhubungan dengan produk, manusia/ tenaga kerja, proses dan tugas, serta lingkungan yang memenuhi atau melebihi harapan pelanggan atau konsumen".

Namun dmeikian, dengan kondisi keterbatasan aparat dan kurangnya kemampuan yang dimiliki oleh sebagian aparat menyebabkan berbagai program bekum mencapai hasil sesuai target yang telah ditetapkan. Hal tersebut cukup berdampak pada beberapa program strategis guna mempromosikan daerah kepada pihak luar baik nasional maupun internasional belum dapat direalisasikan. Di satu sisi organisasi kekurangan data yang akurat tentang potensi yang dimiliki oleh daerah secara keseluruhan, di sisi lain kemampuan kerja dari sebagian aparat belum dilakukan secara maksimal.

Terkendalanya penyelenggaraan tugas dan fungsi tersebut, perlu segera dibenahi dari segenap unsur pimpinan dalam organisasi. Untuk itu, dibutuhkan adanya dukungan yang menyeluruh agar setiap aparat mempunyai ditingkatkan kemampuan atau keahlian untuk 
menghasilkan layanan pemerintahan sesuai target yang telah ditetapkan. Hal itu dapatlah dimaklumi mengingat, tuntutan akan informasi pelayanan tentang potensi daerah yang senantiasa berubah dan bervariasi, menyebabkan setiap aparat, harus mengimbangi perubahan itu dengan peningkatan kemampuan atau keahliannya.

Menyikapi fenomena di atas, maka yang dilakukan oleh segenap unsur pimpinan adalah melakukan pembinaan dan arahan yang dilakukan secara konsisten. Hal itu dimaksudkan untuk mengubah pola pikir setiap aparat untuk dapat menyelenggarakan pelayanan secara handal, sekaligus meminimalisir terjadinya pemborsan penggunaan anggaran. Penyelenggraan pelayanan yang handal dapat dilakukan jika organisasi mampu memperlihatkan kinerja, sesuai dengan arah kebijakan yang telah ditetapkan. Bila kesemuanya itu dapat dilakukan dengan baik sesuai sengan tugas dan fungsi yang dilaksanakan, niscaya akan terbangun tingkat kepercayaan harapan dari pihak yang membutuhkan pelayanan, kepada Badan sebagai organisasi publik.

\section{c. Faktor Timeliness}

Ketepatan waktu penyelesaian layanan sesuai dengan standar dalam organisasi sangat dibutuhkan, sehingga terdapat waktu yang digunakan untuk menyelesaikan pekerjaan lainnya. Di samping standar yang ada dalam organisasi, setiap aparat juga perlu dibekali dengan kemampuan tentang mekanisme dan prosedur layanan sehingga tugas dan fungsi dapat diselesaikan tepat waktunya sesuai yang telah ditetapkan. Hal itu sebagaimana dijelaskan Bernadin dan Russel (2006:239) bahwa "Timeliness: The degree to which activity is comleted, or a result produced, at the earliest time desirable from the standpoikt of both coordinating with the outputs of other and maximizing the time available for other activities". Hal itu memberikan pengertian tentang sejauh mana suatu kegiatan dapat diselesaikan tepat pada waktu yang dikehendaki dengan memperhatikan koordinasi dengan hasil kerja lainnya, serta waktu yang tersedia untuk kegiatan lain.

Sebagai organisasi yang menyelenggarakan pelayanan, Badan Penghubung perlu menempatkan ketepatan waktu dan konsekwen dalam menyelesaikan produk layanan yang diberikan. Sebagaimana dalam pandangan Gasperzs (2007:12) bahwa "pelayanan yang lebih cepat (faster), lebih murah (cheaper) dan lebih baik (better)". Namun demikian, pelayanan yang tepat waktu belum menjadi perhatian dari segenap komponen organisasi untuk meningkatkan kualitas pelayanan. Sikap yang ditunjukkan aparat Para pegawai yang bertugas, memiliki kecendrungan belum serius dalam melaksanakan tugas. Sikap dan perilaku pegawai dalam melaksanakan tugas dan fungsi dalam organisasi, menunjukkan bahwa pegawai masih kurang sungguh-sungguh dalam menjalankan apa yang menjadi tugas dan kewajibannya.

Realitas di lapangan menunjukan bahwa kurangnya tampilan untuk bekerja dengan serius yang dimiliki oleh aparat cukup beralasan, mengingat sebagian aparat dalam melaksanakan tugas dan fungsi, belum mampu menyelesaikan tepat pada waktunya. Dalam menjalankan tugas dan fungsi, terlihat di antara para aparat sering timbul kecuriagaan, dan saling melempar tanggung jawab jika pekerjaan yang dilaksanakannya tidak dapat diselesaikan. Kurangnya ketelitian yang diperlihatkan aparat, karena sebagian aparat belum menguasai mekanisme dan prosedur dan kurangnya kerjasama yang dibangun di antara aparat pelaksana. 
Menyikapi fenomena tersebut diperlukan suatu pemahaman yang terpadu yang ditunjukkan oleh pimpinan organisasi, guna memberikan pemahaman kepada bawahannya tentang pentingnya membangunan kerjasama dalam unit organisasi. Dengan kerjasama yang baik dalam proses pelaksanaan tugas pelayanan kepada masyarakat diharapkan dapat tercipta keharmonisan dilingkungan organisasi. Keharmonisan hubungan dapat terjalin dengan baik, jika di antara sesama bawahan terjalin kerjasama yang harmonis, demikian pula adanya saling asah dan saling asuh antara atasan dan bawahan.

d. Faktor Cost Effectiveness

Keterlibatan seseorang aparatur untuk berpartisipasi dalam merencanakan program kerja, sangat penting dilakukan untuk menumbuhkan dinamika dalam kerja, karena merasa dihargai oleh organisasi. Melalui kemampuan yang dimiliki setiap aparat baik secara individu maupun kelompok dalam organisasi dapat menentukan keberhasilan organisasi mencapai tujuan yang telah ditetapkan. Dengan kemampuan yang dimiliki, pimpinan dapat mengarahkan para bawahannya untuk melaksanakan setiap program secara cepat, tepat, efektif dan efisien sesuai tujuan dan sasaran yang ingin dicapai. Sebagaimana dikatakan Bernadin dan Russel (2006:239) bahwa "Cost effectiveness: The degree to which the use of the organizations resources (e.g., human, monetary, technological, material) is maximized in the sense of getting the highest gain or reduction in loss from each unit or instance of use of a resource". Artinya sejauh mana penggunaan sumber daya organisasi (manusia, modal, teknologi, berbagai fasilitas) dapat dimaksimalkan untuk mencapai hasil maksimal atau pengurangan terhadap kerugian dari setiap unit penggunaan sumber daya.

Realitas di lapangan menunjukan bahwa walupun berbagai program strategis telah disusun, namun belum terlaksana sebagaimana diharapkan. Hal itu disebabkan karena kurangnya kemampuan sebagian aparat dalam melaksanakan program terutama dalam memberikan informasi pelayanan yang akurat tentang potensi yang dimiki daerah. Kondisi yang demikian memperlihatkan bahwa keterlibatan aparat dalam memberikan pelayanan belum sepenuhnya sesuai dengan tugas dan fungsi yang diemban. Untuk itu, perlu adanya perhatian dari segenap unsur pimpinan dalam mengawasi dan membimbing para bawahan untuk menjalankan program sesuai ketentuan yang berlaku.

Dengan kondisi yang demikian, diperlukan berbagai langkah inisiatif untuk menciptakan terobosan dan ide-ide baru dalam kaitannya dengan peningkatan kinerja. Hal itu dapat dilakukan dengan adanya perhatian dari pimpinan untuk memberikan tugas dan pekerjaan kepada setiap aparat secara kontinyu yang ditindaklanjuti dengan pembinaan dan pengawasan, guna merangsang setiap aparat untuk meningkatkan kinerjanya, namun demikian hal itu belum diperlihatkan oleh pimpinan bagi aparat dalam penyelenggaraan tugas dan fungsi.

Padahal munculnya inisiatif dari setiap aparat yang optimal, dimaksudkan untuk menumbuhkan kompetensi, sebagai bentuk pemaknaan dan pemenuhan berbagai aktivitas yang dilakukan sesuai dengan kewenangan yang dimiliki dalam organisasi. Hal ini sejalan dengan apa yang dikemukakan oleh Nugroho (2014:5) bahwa "Inisiatif merupakan sebuah upaya untuk menumbuhkan kompetensi dari masing-masing pegawai dalam kaitannya dengan aktivitas tertentu". Dengan demikian, segenap kemampuan yang dimiliki aparat, perlu dikerahkan sesuai kewenangan yang dimiliki agar program yang telah dicencanakan dapat mencapai target sebagaimana yang ditetapkan. 


\section{e. Faktor Need For Supervision}

Terciptanya sumber daya manusia yang berkualitas perlu dilakukan untuk mengantisipasi perkembangan persaingan global, sehingga diperlukan aparatur yang mempunyai ketrampilan, memiliki berwawasan dan kemampuan yang memadai, serta dapat menciptakan lingkungan kerja yang harmonis. Hal itu sebagaimana dikemukakan Bernadin dan Russel (2006:239) bahwa "Need for supervison: The degree to which a performae can carry out the job function without either having to request supervisory assistance or requiring supervisory intervention to prevent an adverse outcome”. Hal itu memberi arti bahwa tingkat sejauh mana seorang pegawai (aparatur) dapat melaksanakan suatu fungsi pekerjaan tanpa memerlukan pengawasan oleh atasan untuk mencegah dan meminimalisir tindakan yang tidak diinginkan.

Keterlibatan seseorang aparatur dalam proses pengambilan keputusan, akan memberi rangsangan untuk berinovasi dalam memberikan yang terbaik bagi pekerjaan yang ditekuninya karena merasa dihargai, sehingga bertanggung jawab sebagai komitmen terhadap tugas dan fungsi. Kemampuan setiap aparat untuk melakukan inovasi akan muncul secara berdaya guna dan berhasil guna, jika dilibatkan secara aktif dalam setiap aktifitas yang ada dalam organisasi. Sebagaimana dalam pandangan West yang dikutip oleh Sedarmayanti (2017:65) bahwa "Inovasi sebagai pengenalan cara baru yang lebih baik dalam mengerjakan berbagai hal di tempat kerja".

Realitas menunjukan bahwa kemampuan berinovasi yang dimiliki sebagai bentuk keterlibatan aparat, belum sepenuhnya terlihat sesuai dengan tugas dan fungsi yang ada padanya dalam meningkatkan kinerjanya. Padahal tugas dan fungsi yang ada dalam lingkungan organisasi telah didistribusi secara keseluruhan sesuai dengan bidang tugasnya masing-masing. Melalui tugas dan fungsi itu, diharapkan setiap aparat dapat meningkatkan kinerja dengan ide-ide baru, tanpa perlu diawasi dan diarahkan oleh pimpinan. Namun demikian, tidak dapat dipungkiri, bahwa upaya untuk melibatkan setiap aparatur dalam proses penyelenggaraan pelayanan, belum memperoleh hasil sebagaimana yang diinginkan. Hal tersebut disebabkan keterbatasan kemampuan yang dimiliki aparat untuk berinovasi dengan ide-ide baru untuk mempercepat keberhasilan pelaksanaan berbagai program yang telah ditetapkan.

Padahal pengembangan kemampuan aparatur, baik dari pengalaman kerja yang dimiliki atau kesempatan untuk maju merupakan perangsang kuat bagi setiap aparat untuk bekerja lebih giat dan lebih bergairah. Program pelatihan dan pengembangan yang sistematis memberikan motivasi dan kesempatan kepada setiap aparat untuk meningkatkan kemampuan Bintek maupun kursus sesehingga dapat menciptakan lingkungan kerja yang harmonis dalam penyelenggaraan tugas dan fungsi dalam memberikan pelayanan yang berkualitas, namun kesemuanya itu belum terlaksana dengan baik karena kurangnya dukungan anggaran yang memadai dan kesempatan yang diberikan oleh organisasi Pemda.

Fenomena tersebut perlu dicermati melalui adanya langkah-langkah strategis dalam mengembangkan setiap potensi dan kemampuan yang dimiliki aparatur.Upaya meningkatkan mutu pelayanan aparatur harus dimulai dahulu dengan meningkatkan dan mengembangkan kemampuan teknis setiap individu dalam organisasi. Pengembangan sumber daya aparatur diarahkan kepada jalur professional, guna meningkatkan kualitas sesuai dengan kebutuhan organisasi pemerintahan. 


\section{f. Faktor Interpersonal Inpact}

Tersedianya sumber daya aparatur yang memiliki kemampuan, akan mendorongnya untuk bekerja lebih giat yang dilandasi loyalitas, sehingga menimbulkan kegairahan untuk memberikan pelayanan yang berkualitas. Demikian pula, akan mendorong sikap dan perilaku serta semangat kerja dari setiap aparat untuk berusaha demi menyukseskan berbagai program yang telah ditetapkan organisasi sesuai mekanisme dan prosedur kerja secara efektif dan efisien. Pemahaman tersebut sejalan dengan pendapat Bernadin dan Russel (2006:239) bahwa "Interpersonal inpact: The degree to which performer promotes feelings of self-esteem, goodwill, and cooperativeness among co-workers an subordinates". Artinya tingkat sejauh mana pegawai (aparatur) memelihara harga diri, nama baik, danan kerjasama di antara sesama aparat dan bawahan.

Realitasnya menunjukan bahwa aparatur masih kurang sungguh-sungguh menjalankan tugas dan fungsi, sehingga mempengaruhi intensitas penyelesaian berbagai program yang telah ditetapkan. Dalam menjalankan program masih terlihat ada sebagian aparat yang belum dapat menjaga sikap dan perilaku untuk memberikan pelayanan yang terbaik kepada berbagai pihak yang membutuhkan, karena belum yang sesuai prosedur dan mekanisme kerja yang ada dalam organisasi. Hal itu karena, tugas yang diberikan terkadang belum tidak sesuai dengan tugas dan fungsi yang dilaksanakan, karena keterbatasan aparat yang ada.

Permasalahan di atas menyebabkan terdapat beberapa program kerja yang dijalankan, belum mencapai hasil sesuai target yang ditetapkan. Untuk itu perlu adanya perhatian dari segenap unsur pimpinan sub unit untuk mengawasi dan membimbing para bawahan untuk mematuhi aturan dan ketentuan yang berlaku. Namun demikian, tidak dapat dipungkiri, bahwa upaya tersebut belum memperoleh hasil sebagaimana yang diinginkan karenaterbatasnya aparat yang memiliki kemampuan teknis, sehingga sering terjadi program belum terealisasi dengan baik. Selain itu, belum adanya tindakan yang cepat untuk memberikan pelayanan, karena umumnya aparat belum memiliki semangat kerja, kurangnya koordinasi dan komunikasi yang terjalin di antara sesama aparat.

Padahal, lingkungan kerja dapat terjalin baik, jika di antara sesama bawahan terjalin kerjasama yang harmonis dan komunikatif, adanya saling asah dan saling asuh antara atasan dan bawahan. Oleh sebab itu, diperlukan suatu pemahaman yang terpadu yang ditunjukkan oleh pimpinan organisasi, guna memberikan pemahaman kepada bawahannya tentang pentingnya membangun kerjasama yang sifatnya komunikatif dalam organisasi. Kondisi yang demikian akan menimbulkan dampat terhadap peningkatan kinerjanya, terutama dalam memberikan pelayaan, namun hal itu belum terselenggara dengan baik.

Dalam konteks pelayanan pemerintahan, seringkali hambatan itu terjadi karena ketidakmampuan aparatur dalam memberikan informasi secara jelas dan transparan tentang prosedur dan mekanisme pelayanan. Padahal terbangunnya komunikasi harmoni dalam organisasi dengan baik, dalam pengertian jelas dan transparan akan membentuk timbulnya kesamaan persepsi. Dalam hubungan itu, Liliweri (2014:277), menyatakan bahwa "Komunikasi merupakan interaksi antara komunikator dengan komunikan yang mempertukarkan dan memberi makna yang sama atas informasi untuk suatu tujuan tertentu melalui media, metode, tehnik atau cara-cara yang telah ditetapkan". 


\section{Strategi Kinerja Aparatur Yang Tepat dalam Meningkatkan Kualitas Pelayanan di Badan Penghubung Pemerintah Provinsi Kalimantan Tengah di Jakarta}

Langkah pertama perumusan strategi peningkatan kinerja aparatur di Lingkungan Badan Penghubung Pemerintah Provinsi Kalimantan Tengah di Jakarta, dilakukan melalui Analisis SWOT (Strength, Opportunites, Weakness, Threats). Analisis SWOT digunakan untuk menumbuhkan motivasi dan semangat kerja dalam mencapai tujuan organisasi. Melalui pelaksanaan tugas dan fungsi terutama dalam menyelenggarakan layanan pemerintahan, diharapkan tercipta kondisi lingkungan strategis (eksternal maupun internal) yang dinamis sehingga dapat mencapai pelayanan prima.

Penggunaan analisis SWOT didasarkan pada logika yang memaksimalkan melalui, kekuatan (strengths) dan peluang (opportunities), namun secara bersamaan dapat meminimalkan kelemahan (weaknesses) dan ancaman (threats). Keempat unsur tersebut yang selalu dihadapi dan dimiliki oleh suatu organisasi, yang secara internal memiliki kekuatan (strengths) dan kelemahan (weaknesses), serta secara eksternal mengahadapi berbagai peluang (opportunities) dan ancaman (threats).

Penetapan unsur-unsur kekuatan, kelemahan, peluang dan tantangan ini merupakan upaya menghasilkan ide-ide, tujuan-tujuan jangka pendek dan strategi yang membantu untuk mengidentifikasi dan mengkonseptualisasikan kondisi-kondisi permasalahan. Metode ini juga dapat digunakan untuk menghasilkan sejumlah perkiraan-perkiraan mengenai solusi yang potensial bagi masalah-masalah yang ada.

Berdasarkan hasil analisis SWOT dan Uji Litmus Test maka didapatkan empat isu strategis yang selanjutnya dapat menjadi masukan dan pertimbangan bagi Pemerintah Provinsi Kalimantan Tengah sebagai upaya untuk kinerja aparatur dalam meningkatkan kualitas pelayanan di lingkungan Badan Penghubung Pemerintah Provinsi Kalimantan Tengah di Jakarta, sehingga strategi yang disarankan adalah sebagai berikut:

a. Menyusun program-program yang dapat mengembangkan kinerja aparatur guna merangsang peningkatan kualitas pelayanan.

b. Mengembangkan kemampuan aparatur dalam memanfaatkan teknologi dan mengelola informasi, sebagai bentuk kinerja positif.

c. Optimalisasi penggunaan anggaran dalam meningkatkan kemampuan teknis sumber daya aparatur sebagai penggerak organisasi.

d. Meningkatkan motivasi dan semangat kerja aparatur melalui penerapan aturan-aturan yang berlaku, dan penerapan uraian tugas yang jelas.

\section{E. KESIMPULAN}

Kinerja aparatur dalam meningkatkan kualitas pelayanan yang diselenggarakan Badan Penghubung Pemerintah Provinsi Kalimantan Tengah di Jakarta yang tercermin dalam aspek tingkat pendidikan, pengetahuan dan pengalaman belum terlaksana secara optimal. Hal itu disebabkan karena kurangnya tingkat pendidikan yang dimiliki, kurangnya pengetahun dan ketrampilan teknis yang dimiliki, dan kurangnya pengalaman yang dimilik terkait dengan tugas dan fungsi pelayanan yang dilaksanakan oleh aparat, terkait dengan promosi potensi daerah dan menghubungkan pemerintah daerah dengan pemerintah pusat maupun pihak luar belum terselenggara sebagaimana yang diharapkan. 
Belum baiknya kinerja aparatur dalam meningkatkan kualitas pelayanan di Badan Penghubung Pemerintah Provinsi Kalimantan Tengah di Jakarta disebabkan berbagai factor yaitu: 1). Faktor quality belum terselenggara secara optimal, karena kurangnya kemampuan aparat dalam menyelesaikan tugas dan fungsi sesuai mekanisme dan prosedur yang diterapkan sehingga berbagai program yang dilaksanakan belum mencapai hasil sesuai yang diharapkan. 2). Faktor quantity belum dicapai secara optimal, karena kurangnya kemampuan teknis aparat dalam menggunakan sarana dan prasarana yang disediakan pemerintah pemerintah daerah, sehingga berbagai program yang ditetapkan belum mencapai hasil sesuai yang diharapkan. 3). Faktor timeliness belum terselenggara secara optimal, karena berbagai program yang dilaksanakan belum dapat diselesaikan tepat waktu sesuai ketentuan yang berlaku. Demikian pula sebagian aparat kurang teliti dalam penyelenggaraan pelayanan sehingga hasil yang dicapai belum maksimal. yang ditetapkan belum mencapai hasil sesuai yang diharapkan. 4). Faktor cost supervision belum terlaksana secara optimal, karena kurangnya kemampuan aparat dalam melaksanakan berbagai program, karena kurangnya penghargaan yang diberikan organisasi sehingga tugas dan fungsi yang dilaksanakan belum terselenggra secara berkualitas. 5). Faktor need for supervision belum terlaksana secara optimal, karena kurangnya kemampuan aparat dalam melakukan inowasi dalam pelaksanaan program, dan kurangnya rasa tanggung jawab yang diperlihatkan aparat dalam pelaksanaan tugas dan fungsi sehingga targaet yang dicapai belum maksimal. 6). Faktor interpersonal inpact, juga belum terlaksana secara optimal, karena kurangnya tampilan sikap dan perilaku aparat untuk serius sesuai dedikasi dan loyalitas dalam bekerja, serta kurangnya semangat kerja yang dimiliki aparat dalam melaksanakan pelayanan sesuai tugas dan fungsi, sehingga program belum mencapai hasil yang maksimal.

Strategi kinerja aparatur yang tepat digunakan dalam meningkatkan kualitas pelayanan di Badan Penghubung Pemerintah Provinsi Kalimantan Tengah di Jakarta yaitu Menyusun program-program yang dapat mengembangkan kinerja aparatur guna merangsang peningkatan kualitas pelayanan, dan mengembangkan kemampuan aparatur dalam memanfaatkan teknologi dan mengelola informasi, sebagai bentuk kinerja positif.

\section{DAFTAR PUSTAKA}

Alwasilah, A. C. (2011). Pokoknya Kualitatif, (Dasar-Dasar Merancang dan Melakukan Penelitian Kualitatif). Jakarta: Dunia Pustaka Jaya dan Pusat Studi Sunda.

Arikunto, S. (2016). Prosedur Penelitian Suatu Pendekatan Praktik. Jakarta: Rineka Cipta.

Bernardin, H. J., \& Russel, J. E. A. (2006). Manajemen Sumber Daya Manusia. Bandung: Armico.

Gaspersz, V. (2007). Manajemen Kualitas. Jakarta: Gramedia.

Hamdi, M., \& Ismaryati, S. (2014). Metodologi Penelitian Administrasi. Tangerang Selatan: Universitas Terbuka.

Johnston, E. J. (1989). Management Dimentions of Development. Kumarian Press Evers.

Liliweri, A. (2014). Sosiologi dan Komunikasi Organisasi. Jakarta: Bumi Aksara.

Moleong, L. J. (2014). Metodolgi Penelitian Kualitatif. Bandung: Remaja Rosdakarya.

Nasution. M. N. (2001). Manajemen Mutu Terpadu (Total Quality Management). Jakarta: GhaliaIndonesia. 
Nazir, M. (2011). Metodologi Penelitian. Jakarta: Ghalia Indonesia.

Ndraha, T. (1985). Peranan Administrasi Pemerintahan Desa dalam Pembangunan Desa. Jakarta: Yayasan Karya Dharma IIP.

Nugroho, R. (2014). Kebijakan Publik (Formulasi, Implementasi dan Evaluasi). Jakarta: Elex Media Komputindo.

Rasyid, M. R. (2003). Kajian Awal Birokrasi Pemerintahan dan Politik Orde Baru. Jakarta: Yarsif Watampone.

Robbins, S. P. (2006). Perilaku Organisasi. Jakarta: Prinhalindo.

Sanjaya, W. (2006). Strategi Pembelajaran Berorientasi Standar Proses Pendidikan. Bandung: Kencana.

Sedarmayanti. (2017). Manajemen Sumber Daya Manusia, Reformasi Birokrasi dan Manajemen Pegawai Negeri Sipil. Bandung: Refika Aditama.

Strauss, A., \& Juliet, C. (2003). Basics of Qualitative Research: Grounded Theory, Procedures And Techniques. California: Sage Publications.

Sutrisno, E. (2016). Manajemen Sumber Daya Manusia. Bandung: Mulia Kencana Semesta.

Thoha, M. (2008). Perilaku Organisasi-Konsep Dasar dan Aplikasinya. Jakarta: Raja Grafindo Persada.

Wasistiono, S., \& Tahir, I. (2007). Prospek Pengembangan Desa. Bandung: Fokusmedia.

Wibowo. (2017). Perilaku Dalam Organisasi. Jakarta: Raja Grafindo Persada.

Zainun, B. (2001). Manajemen Sumber Daya Manusia Indonesia. Jakarta: Toko Gunung Agung. 